\title{
SCREENING OF ACTINOMYCETES FROM EARTHWORM CASTINGS FOR THEIR ANTIMICROBIAL ACTIVITY AND INDUSTRIAL ENZYMES
}

\author{
Vijay Kumar ${ }^{1}$; Alpana Bharti ${ }^{1}$; Yogesh Kumar Negi ${ }^{1}$; Omprakash Gusain ${ }^{2}$; Piyush Pandey ${ }^{1}$; Gajraj Singh Bisht ${ }^{{ }^{*}}$ \\ ${ }^{1}$ Department of Microbiology, Sardar Bhagwan Singh Post Graduate Institute of Biomedical Sciences and Research, Balawala, \\ Dehradun, Uttarakhand, India, 248161; ${ }^{2}$ Department of Zoology and Biotechnology, H.N.B. Garhwal University, Srinagar, \\ Uttarakhand, India.
}

Submitted: March 14, 2011; Returned to authors for corrections: June 22, 2011; Approved: August 30, 2011.

\begin{abstract}
Actinomycetes from earthworm castings were isolated and screened for their antimicrobial activity and industrial enzymes. A total of 48 isolates were obtained from 12 samples of earthworm castings. Highest numbers of isolates were recovered from forest site $(58.33 \%)$ as compared to grassland $(25 \%)$ and agricultural land $(16.66 \%)$. The growth patterns, mycelial coloration of abundance actinomycetes were documented. The dominant genera Identified by cultural, morphological and physiological characteristics were Streptomyces (60.41\%) followed by Streptosporangium (10.41\%), Saccharopolyspora $(6.25 \%)$ and Nocardia (6.25\%). Besides these, other genera like Micromonospora, Actinomadura, Microbispora, Planobispora and Nocardiopsis were also recovered but in low frequency. Among the 48 isolates, 52.08\% were found active against one or more test organisms. Out of 25 active isolates $16 \%$ showed activity against bacterial, human fungal as well as phytopathogens. Among 48 isolates 38, 32, 21, 20, 16 and 14 produced enzyme amylase, caseinase, cellulase, gelatinase, xylanase and lipase respectively while 10 isolates produced all the enzymes. More interestingly 2, 3, and 1 isolates produced amylase, xylanase and lipase at $45^{\circ} \mathrm{C}$ respectively. In the view of its antimicrobial activity as well as enzyme production capability the genus Streptomyces was dominant. The isolate EWC 7(2) was most promising on the basis of its interesting antimicrobial activity and was identified as Streptomyces rochei. The results of these findings have increased the scope of finding industrially important actinomycetes from earthworm castings and these organisms could be promising sources for industrially important molecules or enzymes.
\end{abstract}

Key words: Antimicrobial activity, enzymes, earthworm castings, actinomycetes

\section{INTRODUCTION}

The development of multidrug resistance in pathogenic organisms is continuous problem faced by currently used antibiotics (3). Therefore, the availability of potent drug is becoming particularly an acute problem (30). In this scenario, microorganisms have been intensively screened from soil as a source of therapeutically important molecules over a half

*Corresponding Author. Mailing address: Department of microbiology, Sardar Bhagwan Singh Post Graduate Institute of Biomedical Sciences and Research, Balawala, Dehradun, Uttarakhand, India, 248161.; Tel.: +91-9719148874.; E-mail: grsbisht@gmail.com 
century (11) however; the frequency of discovery of structurally new compounds is apparently decreasing these years. This trend seems to imply that the easily accessible microorganisms in soil had been exhausted and there is a need to seek unutilized microorganisms from unexplored sources (16). It is likely that the diversity of secondary metabolites relies more or less on the isolation source, namely, the habitat of the producers (16). On the basis of above facts new actinomycetes strains that generate active compounds have been recently isolated from novel sources including saline, ocean, mangrove forests and niche habitats such as caves, pristine forests, lakes, rivers, and other wetlands $(29,31)$. To cope up with the demand for new pharmaceutical compounds and to combat the antibiotic resistant pathogens, researchers have been forced to look for novel microorganisms in unusual and unexplored environments.

The earthworm casting has rarely been explored for actinomycetes having antimicrobial activity and industrial enzymes. Extensive literature survey revealed that the casting activity led to nutrition and microbial enrichment (36). Hence, the number of total bacteria, siderophore producing bacteria and fluorescent Pseudomonads were greater in casts as compare to the soil without casting activity (7) but there was no report on actinomycetes. The interaction between earthworm, beneficial soil microorganisms and root pathogens had been studied by Doube et al (8) and found that earthworms act as vectors for beneficial soil bacteria. Hence, there is an immense possibility to identify new actinomycetes in the earthworm casting to discover novel bioactive compounds. Accordingly, the present study was aimed to screen industrially important actinomycetes in the earthworm castings with the ultimate objective of discovering novel bioactive compounds.

\section{MATERIALS AND METHODS}

\section{Sampling area}

The study area covered the Doon valley (Dehradun) of Uttarakhand, India. The latitude and longitude of Dehradun is $30^{\circ} 20^{\prime} \mathrm{N}$ and $78^{\circ} 04^{\prime} \mathrm{E}$ respectively. It is 660 meters above the sea level. In summer the temperature is minimum of $16.7^{\circ} \mathrm{C}$ and maximum of $36^{\circ} \mathrm{C}$. The average rain fall is $2073.3 \mathrm{~mm}$.

\section{Collection of samples}

A total of 12 earthworm (Pheretima posthuma) castings were collected during rainy season in the month of August 2008 from different places of Doon valley, Uttarakhand, India. Four Samples were collected from each site e.g. forest, agricultural land and grassland (Table 1). The earthworm castings were carefully taken with spatula and kept in sterile polypropylene bags. The collected earthworm castings were taken to the laboratory for isolation of actinomycetes.

\section{Measurement of pH}

The $\mathrm{pH}$ of all the samples was determined by $\mathrm{pH}$ meter (Toshcon, Ajmer, India). Ten grams of each sample was suspended in $20 \mathrm{~mL}$ of distilled water and allowed to stand for 20 minutes with occasionally stirring to reach equilibrium. After being left to settle, the $\mathrm{pH}$ was measured.

\section{Isolation of actinomycetes}

Actinomycetes were isolated using both selective and non selective methods. For non selective isolation, $1.0 \mathrm{~g}$ of soil from each sample was dissolved in $10 \mathrm{~mL}$ sterile normal saline and serially diluted up to $10^{-3}$ and plated $(1 \mathrm{~mL})$ on yeast malt extract agar medium (yeast extract, $4.0 \mathrm{~g} / \mathrm{L}$; malt extract, 10.0 g/L; dextrose, 4.0 g/L; agar, 20 g/L (HiMedia, India), ISP-2 (37) containing cycloheximide (HiMedia, India) and nystatin (50 $\mu \mathrm{g} / \mathrm{mL}$ each, (HiMedia, India) in order to minimize fungal contamination. The plates were incubated for 2 to 3 weeks at $27^{\circ} \mathrm{C}$. Selective isolation was done by 3 methods i.e. (a) $1 \mathrm{~g}$ of sample was pre-treated at $80-85^{\circ} \mathrm{C}$ for $1 \mathrm{~h}$ and cooled down to room temperature. Preparation of serial dilution and plating was done according to method mentioned in non selective isolation. (b) $1 \mathrm{~g}$ of soil sample was dissolved in $10 \mathrm{~mL}$ sterile distilled water and serially diluted up to $10^{-3}$ and plated on Humic acid Vitamin (HV) agar $(12,13)$. (c) Soil sample was pre-treated at $120^{\circ} \mathrm{C}$ for $1 \mathrm{~h}$ serially diluted and plated on $\mathrm{HV}$ agar supplemented with nalidixic acid $(14,15)$. 


\section{Identification of actinomycetes}

The appearance and growth of actinomycetes were observed everyday on their respective plates. The isolates, which showed good growth in 4 days, were considered as fast growers and those that showed good growth between 4 and 7 days were classified as moderate growers and the slow growers took more than 7 days for their growth. All the actinomycetes colonies were picked up, purified, sub cultured on ISP-2 slants and incubated at room $27^{\circ} \mathrm{C}$ for 3-4 weeks. The well sporulated cultures were preserved in $20 \%$ glycerol vials at $-80{ }^{\circ} \mathrm{C}$. All strains were characterized morphologically and physiologically according to the methods described in the International Streptomyces project (37) and Bergey's Manual of Systematic Bacteriology (25). The cover slip culture technique was used to study the morphological characteristics such as substrate and aerial mycelia, spores in chains, forms of chain i.e. rectiflexibilis, retinaculiperti, spirals etc. The cell wall diamiopimelic acid isomers and whole cell sugars were determined according to the method described in IMTECH Laboratory manual (17). Important isolates were identified on the basis of $16 \mathrm{~S}$ rDNA sequence homology as described previously (24)

\section{Screening of actinomycetes for their antimicrobial activity}

All the actinomycete isolates were screened for antibacterial and antifungal activity by agar plug method (9). The actinomycete isolates were spread over the entire surface of ISP- 2 medium. As soon as the actinomycete isolates developed, agar discs were cut out by the cork borer $(6 \mathrm{~mm}$ diameter). These plugs were transferred to the surface of Mueller Hinton agar plates seeded with the human bacterial pathogens (Staphylococcus aureus MTCC2940, Bacillus subtilis MTCC441, Escherichia coli MTCC739, Pseudomonas aeruginosa MTCC424) and on sabouraud dextrose agar plates seeded with human fungal pathogens (Candida albicans MTCC1637, Microsporum canis MTCC2820 and Trichophyton rubrum MTCC296, Aspergillus fumigatus MTCC3070) and plant pathogens (Macrophomina phaseolina,
Fusarium oxysporum and Rhizoctonia solani). The Petri dishes were then kept in incubator at $37^{\circ} \mathrm{C}$ for bacterial pathogens and $27^{\circ} \mathrm{C}$ for fungal pathogens at $24,72 \mathrm{~h}$ respectively. If the antibiotic produced by the organism inhibits the growth of the test organism, a clear zone is formed round the discs. The plant pathogens were obtained from Department of microbiology, Sardar Bhagwan Singh P.G. Institute of biomedical sciences and research, Balawala, Dehradun. The experiments were conducted in triplicates and mean reported as results.

\section{Screening of actinomycetes for their extracellular enzymes production}

Lipolytic activity was detected using the method described by Sierra (38). Xylanase production was determined in basal salts agar medium containing oat spelt xylan $(0.5 \%$, HiMedia, India). The plates of basal medium salt with oat spelt xylan were inoculated with actinomycetes and incubated at $28^{\circ} \mathrm{C}$ for 1-2 weeks. The developed colonies were assayed for xylanase activity by Congo red staining method (5). Plates were flooded with Congo red $(0.1 \%$, HiMedia, India) for $15 \mathrm{~min}$ and then washed with $1 \mathrm{M} \mathrm{NaCl}$ (HiMedia, India), the colonies showing halos around them were recorded positive for xylanase activity. Detection of extracellular cellulase production by actinomycetes was checked by way of plate assay (20). The production of caseinase gelatinase and amylase was determined according to standard methods (1).

\section{RESULTS AND DISCUSSION}

The history of new drug discovery processes shows that novel skeletons have, in the majority of cases, come from natural sources (4). This involves the screening of microorganisms and plant extracts, using a variety of models (34). Today, the emphasis is on the exploration of unusual and previously ignored ecosystems (6). In this scenario, it is important to screen actinomycetes from different unexplored habitats, which may prove to be the important sources of potent molecules. Among bacteria, the actinomycetes are the most important source of bioactive compounds and many clinically 
relevant antibiotics in use today, and may continue to be so (3). This study was focused on earthworm castings because earthworms redistribute organic matter within the soil, increase soil permeability and increase microbial activity by their burrowing and feeding activities (40). Hence, an effort had been made to explore the actinomycetes from earthworm castings for their antagonistic activity and industrial enzymes. A total of 12 earthworm casting samples were collected from different locations of Doon valley, India (Table 1). The $\mathrm{pH}$ of the earthworm casting was ranged from 7.8-8.5, which is suitable for actinomycetes (41). A total of 48 actinomycetes were isolated from earthworm castings, out of which 28 (58.33\%), $12(25 \%)$ and $8(16.66 \%)$ from samples of forest, grass land and agricultural land respectively (Table 1). Moreover, highest numbers of isolates i.e. 34 were recovered from non selective methods as compared to selective isolation methods. The heating of soil samples at $120{ }^{\circ} \mathrm{C}$ or $100{ }^{\circ} \mathrm{C}$ and dry-heat in combination with chemical pretreatments, reduced the numbers of filamentous bacteria and streptomycetes on isolation plates, resulting in the selective isolation of various rare actinomycetes genera $(12,13,32)$. All the isolated actinomycetes from castings were checked for growth rate on ISP-2 medium. It was observed that out of 48 isolates, 14 $(29.16 \%)$ were fast growers, $30(62.5 \%)$ exhibited moderate growth and $4(8.33 \%)$ were slow growers (Figure 1). All the isolates were also grouped on basis of colour series. Four main classes of colour were observed, often with colour intergrades seen within a class. The main colours were white $(45.83 \%)$, gray $(35.41 \%)$, red $(6.25 \%)$, and yellow $(4.16 \%)$ while $8.33 \%$ isolates were without any distinct colour (hyaline) (Figure 2). Occurrence of these colours has been documented previously $(23,37)$. The variations in the colours of the aerial mycelia of the isolates may be an indication contributing to diversity or variability of the isolated actinomycetes.

Table 1. Details of sampling site and isolation of actinomycetes from the Earthworm castings (Pheretima posthuma)

\begin{tabular}{llcc}
\hline Location & Collection site & pH & No. of isolates \\
\hline Dehradun & Forest & 8.5 & 28 \\
& Grassland & 8.0 & 12 \\
& Agricultural land & 7.5 & 8 \\
\hline Total & & & 48 \\
\hline
\end{tabular}

Four samples were collected from each site

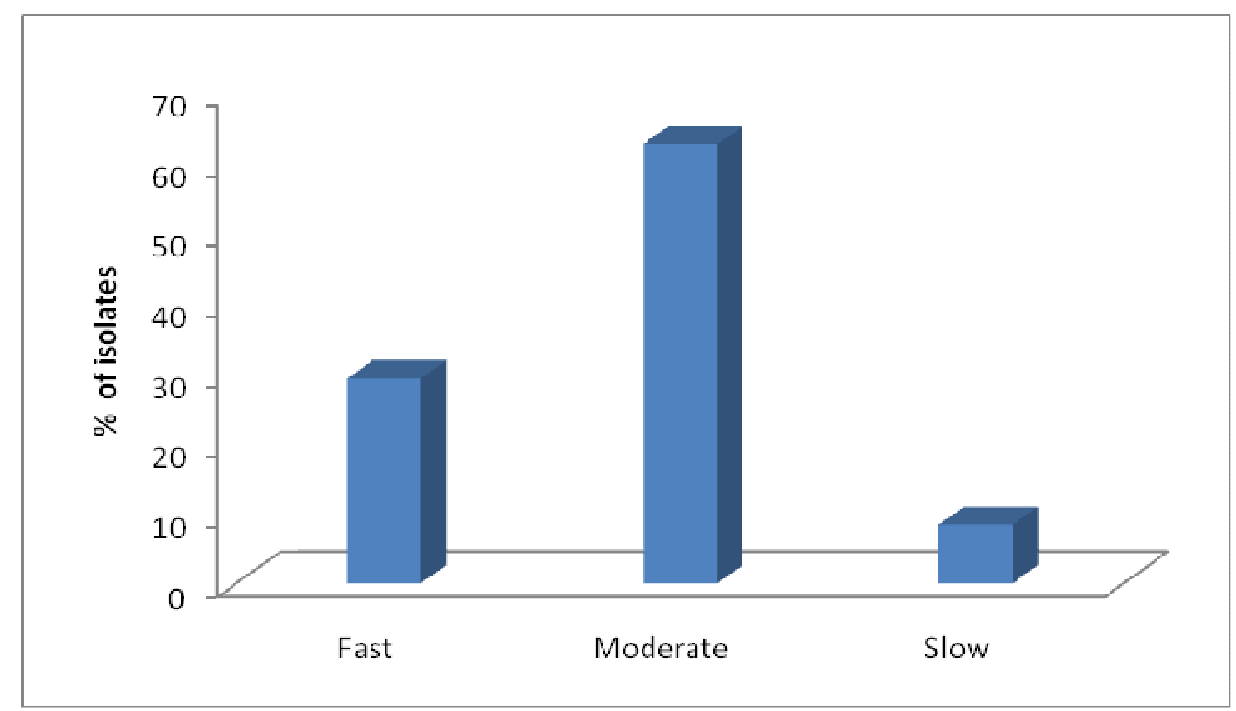

Figure 1. Growth characteristics of actinomycetes isolated from the earthworm castings 


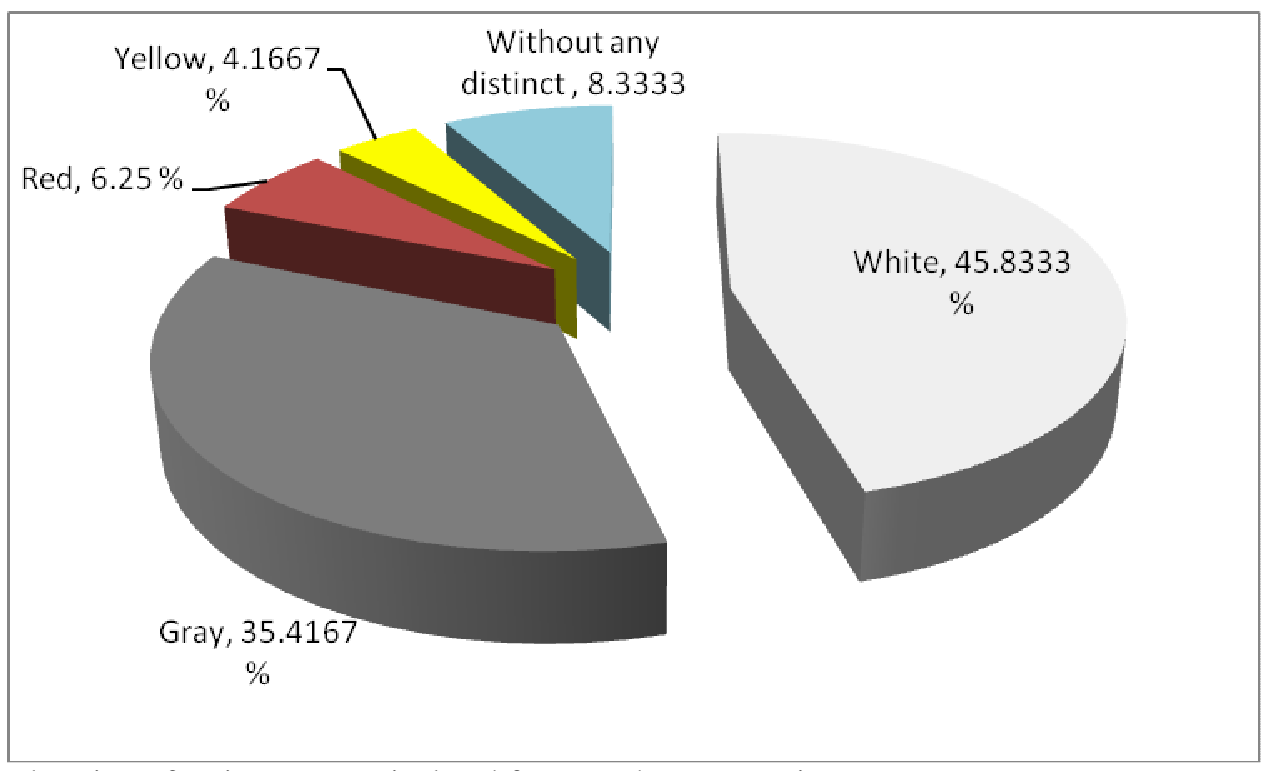

Figure 2. Mycelial coloration of actinomycetes isolated from earthworm castings

On the basis of cultural, morphological and physiological characteristics, the predominant genera were Streptomyces $(60.41 \%, \mathrm{n}=29)$ followed by Streptosporangium (10.41\%, $\mathrm{n}=5)$, Saccharopolyspora $(6.25 \%, \mathrm{n}=3)$ and Nocardia $(6.25$ $\%, \mathrm{n}=3)$. Besides these, other genera like Micromonospora, Actinomadura, Planobispora and Nocardiopsis were also isolated but in low frequency (Figure 3). One isolate did not bear any spore characteristics hence could not be identified. Similarly, Streptomyces albus, S. somaliensis, Nocardia asteroids, N. caviae and Saccharomonospora were isolated from gut and castings previously (33) however, Jayasinghe and Parkinson (18) reported only the species of Streptomyces from castings that were antagonistic to the common litter and wood decomposer fungi. Mba (27) reported 9 strains of Streptosporangium from earthworm castings having phosphate solubilizing activity but there was no detail of their antimicrobial activity.

The degree of antimicrobial activity varied greatly. Among the 48 isolates, $25(52.08 \%)$ were found active against one or more test pathogens. The percentage of isolates that showed antibacterial and antifungal activities only were equal (28\% each). However, 6 (24\%) isolates were found active against both bacteria and fungus (human), and 1 (4\%) exhibited activity against bacteria as well as phytopathogens (Figure 4a). More interestingly $4(16 \%)$ isolates showed activity against bacterial, human fungal pathogens as well as phytopathogens. The detailed antimicrobial activity of actinomycetes had been given in Table 2. During the study it was recorded that the antagonistic potential of Streptomyces was dominant (64\%, $\mathrm{n}=16)$ as compare to Streptosporangium $(12 \%, \mathrm{n}=3)$, Actinomadura $(8 \%, \quad \mathrm{n}=2), \quad$ Nocardia $(8 \%, \quad \mathrm{n}=2)$, Saccharoployspora $(4 \%, \mathrm{n}=1)$, Nocardiopsis $(4 \%, \mathrm{n}=1)$ and Planobispora $(4 \%, \mathrm{n}=1)$ (Figure $4 \mathrm{~b}$.). This is in accordance with the previous reports that the Streptomyces cover around $80 \%$ of the total antibiotic products as compared to other genera (21). However, in recent years antibiotics like Meroparamycin (10), Chromomycins (45), milbemycin (44), JBIR-52 a new antimycin like compound (22) have been reported from Streptomyces species. Likewise antibacterials, antifungal agents have a wide application in human medicine, agriculture and veterinary medicine $(28,43)$. As antibiotic producers or hyperparasites of fungi, actinomycetes have played an important role in controlling soil-borne plant pathogens. The antagonistic impact of actinomycete species on 
pathogenic fungi is well known and a few species have been used as biological control agents $(26,39,46)$. Isolate EWC 7

(2) was found to be most prominent in the terms of desirable activities. It was found to have excellent antimicrobial potential against several bacterial and fungal pathogens. EWC 7(2) was identified as Streptomyces rochei (99\%) on the basis of phylogenetic analysis of 16S rDNA sequences (GQ340692).

In recent years enzymes gained considerable attention in industrial process and replaced the chemical catalysts in various pharmaceuticals, textiles, paper, food industries etc. However, from terrestrial soil samples various enzymes have been reported by various workers (35). In this study we have also explored the actinomycete producing extracellular enzymes. During the study it was recorded that out of 48 isolates 38 (79.16\%), 32 (66.66\%), 21 (43.75\%), 20 (41.66\%), $16(33.33 \%)$ and $14(29.16 \%)$ produced enzyme amylase, caseinase cellulase, gelatinase, xylanase and lipase respectively (Figure 5). Similarly, Mba (27) isolated Streptosporangium from earthworm castings that produced cellulases. It was found that a total of 10 isolates (EWC 2, EWC 5, EWC 8, EWC 18, EWC 22, EWC 30, EWC 41, EWC 44, EWC45 and EWC 47) produced all the five enzymes. More interestingly, the isolates such as Streptoporangium sp. EWC 5, Streptomyces sp. EWC 18 produced amylase, Planobispora sp. EWC 22, Actinomadura EWC 41, and Streptomyces sp. EWC 7(2) produced xylanase while EWC 7(2) showed lipolytic activity at 45 C. The enzyme activity was experimented at high temperature because thermo tolerant enzymes are required for industrial purposes. The majority of actinomycetes isolates from earthworm castings produced amylase followed by caseinase cellulose, gelatinase, xylanase and lipase. Majority of enzymes were produced by the genera Streptomyces supporting the previous reports $(2,19)$. Likewise, an alkaline protease was reported from a salt- tolerant and alkaliphilic, Streptomyces clavuligerus strain MIT-1(42).

Actinomycetes from earthworm castings produced various metabolically active compounds and industrially important enzymes, hence reflecting its importance in view of its economic value. The study revealed that earthworm castings are potential source for a wide spectrum of antimicrobial and industrial enzyme producing actinomycetes. Moreover, it can be an imperative resource for bio prospecting novel/ rare Streptomyces spp., which could yield valuable bioactive molecules.

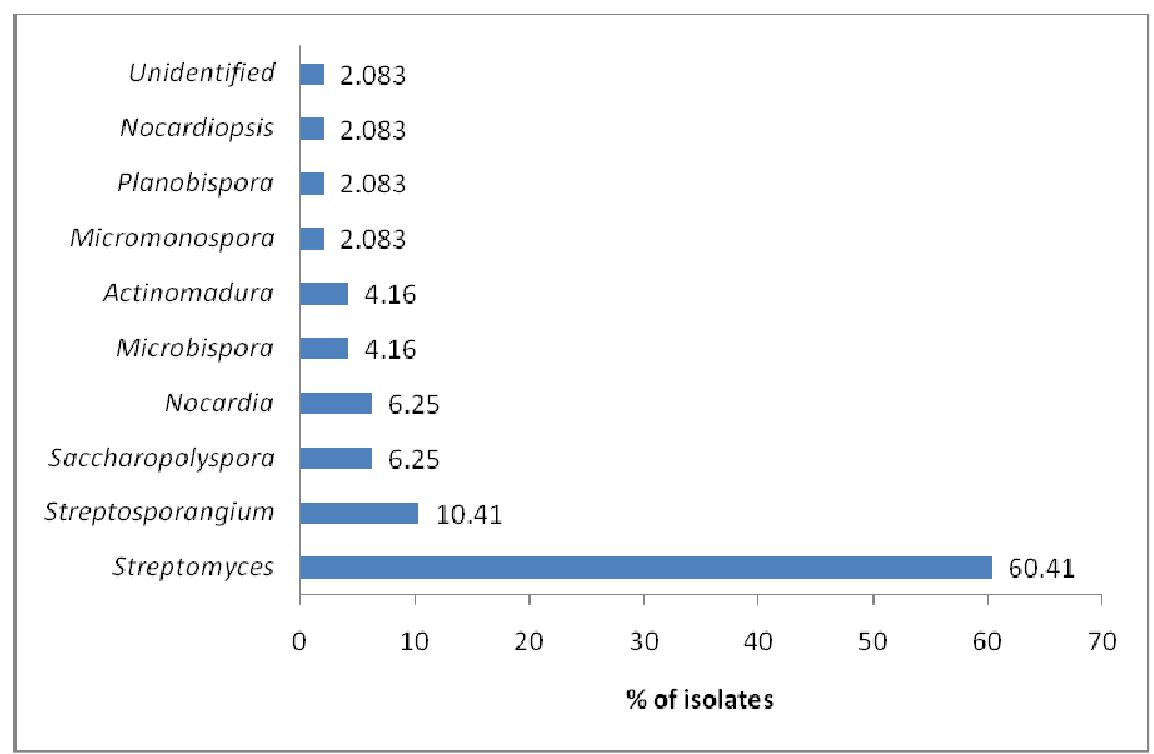

Figure 3. Distribution of actinomycetes in earthworm casting (Identified using cultural, morphological and physiological characteristics) 


\begin{tabular}{|c|c|c|c|c|c|c|c|c|c|c|c|c|}
\hline \multirow[t]{2}{*}{ Isolates } & \multirow[t]{2}{*}{ Genera } & \multicolumn{4}{|c|}{ Bacterial test organisms (IZD)* } & \multicolumn{4}{|c|}{ Human fungal pathogens (IZD)* } & \multicolumn{3}{|c|}{ Phytopathogens (IZD)* } \\
\hline & & $\mathbf{S A}$ & BS & $\mathbf{E C}$ & PS & CA & TR & MC & $\mathbf{A F}$ & MP & FO & $\mathbf{R S}$ \\
\hline EWC 1 & Streptomyces & $15.6 \pm 1.24$ & $17.6 \pm 0.47$ & $12.6 \pm 0.94$ & $10.3 \pm 0.47$ & $14.0 \pm 1.63$ & - & - & $9.6 \pm 0.47$ & - & - & - \\
\hline EWC2 & Streptomyces & $19.0 \pm 0.81$ & $20.3 \pm 1.24$ & $9.0 \pm 0.81$ & $9.3 \pm 0.47$ & - & - & - & - & $17.6 \pm 0.47$ & $19.33 \pm 0.94$ & $17.3 \pm 0.47$ \\
\hline EWC 3 & Streptomyces & $16.6 \pm 1.69$ & - & - & - & - & - & - & - & - & - & - \\
\hline EWC 4 & Micromonospora & - & - & - & - & $20.0 \pm 1.41$ & - & - & - & $13.3 \pm 0.47$ & $16.3 \pm 1.24$ & $15.6 \pm 1.69$ \\
\hline EWC 5 & Streptosporangium & $26.6 \pm 1.24$ & - & - & - & - & - & - & - & - & - & - \\
\hline EWC 6 & Nocardia & - & - & - & - & - & - & - & $10.0 \pm 0.00$ & - & - & - \\
\hline EWC 7(2) & Streptomyces & $25.0 \pm 2.00$ & $26.0 \pm 0.81$ & $24.0 \pm 0.58$ & $17.0 \pm 0.58$ & $20.0 \pm 0.47$ & $19.0 \pm 0.81$ & $18.3 \pm 0.47$ & - & $29.6 \pm 0.47$ & $21.3 \pm 0.94$ & $24.3 \pm 0.94$ \\
\hline EWC 8 & Streptomyces & $20.0 \pm 0.81$ & $16.3 \pm 0.94$ & $10.3 \pm 0.47$ & $9.6 \pm 0.47$ & - & - & - & - & - & - & - \\
\hline EWC 9 & Nocardiopsis & $14.6 \pm 0.94$ & - & - & - & - & - & - & - & - & - & \\
\hline EWC 11 & Streptomyces & $25.0 \pm 1.63$ & $20.6 \pm 0.94$ & - & - & - & - & $15.6 \pm 0.94$ & - & - & - & - \\
\hline EWC 12 & Streptomyces & - & - & - & - & - & $21.0 \pm 0.81$ & - & - & - & - & - \\
\hline EWC 14 & Nocardia & $19.33 \pm 0.47$ & - & - & - & - & $15.3 \pm 0.47$ & - & - & - & $12.0 \pm 0.00$ & - \\
\hline EWC15 & Streptomyces & - & - & - & - & - & - & - & - & - & - & $17.0 \pm 1.87$ \\
\hline EWC 18 & Streptomyces & $27.6 \pm 0.94$ & $23.0 \pm 0.00$ & - & - & - & $10.6 \pm 0.47$ & - & - & - & $10.00 \pm 0.00$ & - \\
\hline EWC 19 & Streptomyces & $13.6 \pm 1.24$ & $16.0 \pm 1.41$ & - & - & $17.6 \pm 0.124$ & - & - & - & - & - & $20.1 \pm 0.62$ \\
\hline EWC 20 & Streptomyces & $17.3 \pm 1.24$ & - & - & - & - & $15.6 \pm 1.05$ & - & - & - & - & - \\
\hline EWC 22 & Planobispora & - & - & - & $12.6 \pm 0.94$ & - & $16.0 \pm 0.00$ & - & - & - & - & - \\
\hline EWC 24 & Saccharopolyspora & - & - & - & $14.0 \pm 0.81$ & - & - & - & - & - & - & - \\
\hline EWC 30 & Streptomyces & - & - & - & - & $19.3 \pm 1.02$ & - & - & - & - & - & - \\
\hline EWC 41 & Actinomadura & - & - & $17.0 \pm 1.41$ & - & - & - & - & - & - & - & - \\
\hline EWC43 & Streptomyces & - & - & $17.3 \pm 0.47$ & - & $18.5 \pm 0.70$ & - & - & - & - & - & - \\
\hline EWC44 & Streptomyces & - & - & - & - & $15.0 \pm 0.00$ & - & $9.8 \pm 1.54$ & - & - & - & - \\
\hline EWC 45 & Streptomyces & - & $18.0 \pm 0.81$ & - & - & & - & - & - & - & - & - \\
\hline EWC46 & Streptosporangium & - & - & - & - & - & $17.6 \pm 0.62$ & - & - & - & - & - \\
\hline EWC 47 & Streptomyces & - & - & $11.3 \pm 1.24$ & - & - & - & $11.1 \pm 1.02$ & - & - & - & - \\
\hline
\end{tabular}




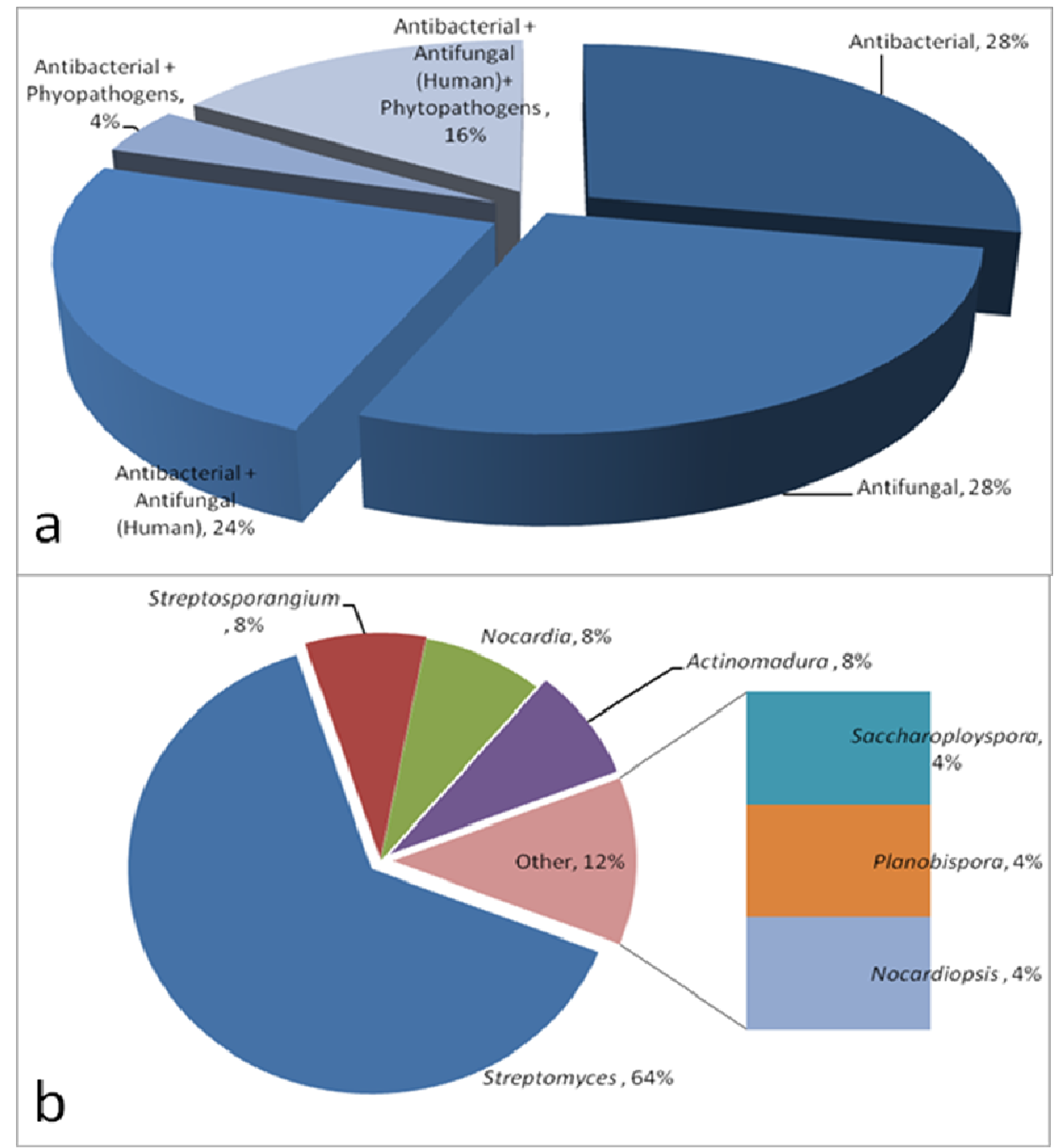

Figure 4. (a) Antimicrobial profile of actinomycetes isolated from earthworm casting (b) Antagonistic potential of genus Streptomyces as compare to other genera

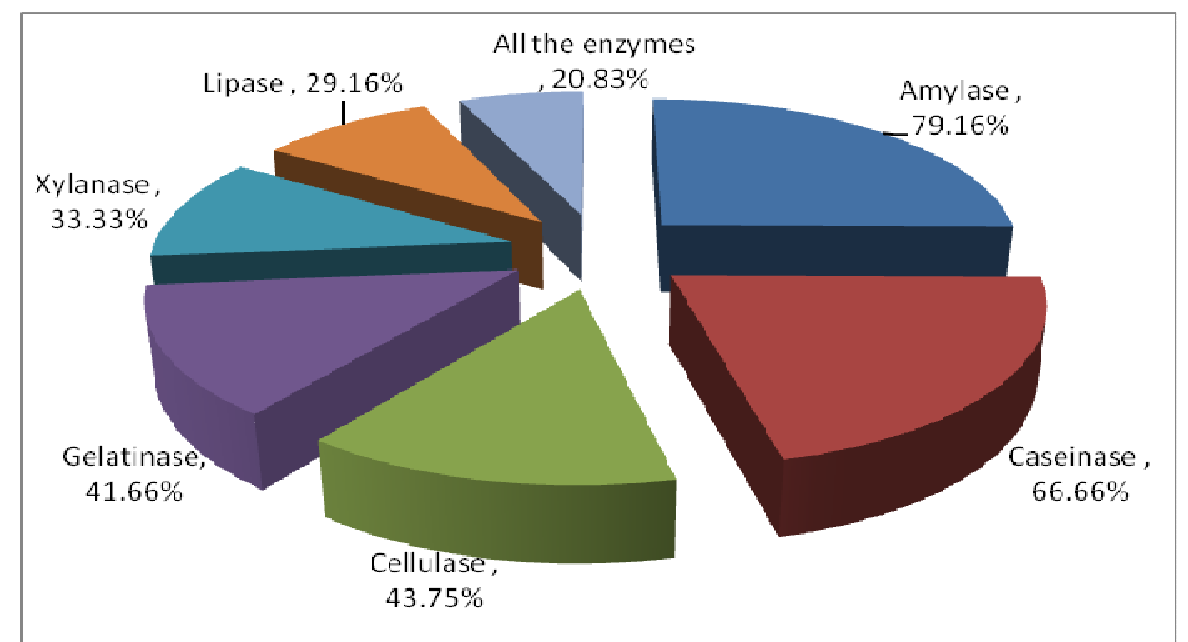

Figure 5. Extracellular enzymes production in actinomycetes isolated from earthworm castings (The data is not mutually exclusive) 


\section{ACKNOWLEDGEMENTS}

Authors are thankful to Uttrakhand State Council for Science and Technology (UCOST), Government of Uttarakhand, India, for providing financial support (File No. UCS \&T/R\&D/LS/06-07/1158).

\section{REFERENCES}

1. Aneja, K.R. (2004). Experiments in Microbiology, Plant Pathology and Biotechnology. New age international publishers, New Delhi, India

2. Ball, A.S.; Mc Carthy, A.J.M. (1989). Production and properties of xylanases from actinomycetes. Appl. Bacteriol. 66, 439- 44.

3. Baltz, R. (2007). Antimicrobials from actinomycetes: Back to Future. Microbe. 2, 125-131.

4. Bevan, P.; Ryder, H.; Shaw, I. (1995). Identifying small-molecule lead compounds: The screening approach to drug discovery. Trends. Biotechnol. 13, 115-121.

5. Breccia, J.D.; Castro, G.R.; Baigari, M.I.; Sneriz, F. (1995). Screening of xylanolytic bacteria using a colour plate method. J. Appl. Bacteriol. 78, 469-472.

6. Cragg, G.M.; Newman, D.J.; Snader K.M. (1997). Natural products in drug discovery and development. J. Nat. Prod. 60, 52-60.

7. Devliegher, W.; Verstraete, W. (1998). Microorganisms and soil physicchemical conditions in the drilosphere of Lumbricus terrestris. Soil Biol. Chem. 30, 795-804.

8. Doube, B.M.; Stephens, P.M.; Davoren, C.W.; Ryder, M.H. (1994). Interaction between earthworms, beneficial soil microorganisms and root pathogens. Appl. Soil Ecol. 1, 3-10.

9. Egorov, N.S. (1985). Antibiotics: A scientific approach. MIR Publishers, Moscow.

10. El-Naggar M.Y.; El-Assar S.A.; Abdul-Gawad S.M. (2006) Meroparamycin Production by Newly Isolated Streptomyces sp. Strain MAR01: Taxonomy, Fermentation, Purification and Structural Elucidation. J. Microbiol. 44, 432-438.

11. Fenical, W. (1993). Chemical studies of marine bacteria: developing a new resource. Chem. Rev. 93, 1673-1683.

12. Hayakawa, M.; Nonomura, H. (1987a). Humic acid-vitamin agar, a new medium for the selective isolation of soil actinomycetes. J. Ferment. Technol. 65, 501-509.

13. Hayakawa, M.; Nonomura, H. (1987b). Efficacy of artificial humic acid as a selective nutrient in $\mathrm{HV}$ agar used for the isolation of soil actinomycetes. J. Ferment. Technol. 65, 609-616.

14. Hayakawa, M.; Sadakata, T.; Kajiura, T.; Nonomura, H. (1991a). New methods for the highly selective isolation of Micromonospora and
Microbispora from soil. J. Ferment. Bioeng. 72, 320-326.

15. Hayakawa, M.; Takeuchi, T.; Yamazaki, T. (1996a). Combined use of trimethoprim with nalidixic acid for the selective isolation of actinomycetes from soil. Actinomycetol. 10, 80-90.

16. Igarashi, Y. (2004). Screening of Novel Bioactive Compounds from Plant-Associated Actinomycetes. Actinomycetol. 18, 63-66.

17. IMTECH (1998). Chemosystematics. In: Chakrabarti, T. (ed). Laboratory manual for identification of actinomycetes. Institute of Microbial Technology, Chandigarh, India. p. 44-46.

18. Jayasinghe, B.A.T.D.; Parkinson, D. (2009). Earthworms as the vectors of actinomycetes antagonistic to litter decomposer fungi. Appl. Soil Ecol. $43,1-9$.

19. Johnson, K.G., Harrison, B. A., Schneider, H., MacKenzie, C.R. and Fontana, J.D. (1988). Xylan-hydrolysing enzymes from Streptomyces spp. Enzy. Microbial. Technol. 10, 403-409.

20. Kasana, R.C.; Salwan, R.; Dhar, H.; Dutt, S.; Gulati, A. (2008). A Rapid and Easy Method for the Detection of Microbial Cellulases on Agar Plates Using Gram's Iodine. Curr. Microbiol. 5, 503-507.

21. Kieser, T.; Bibb, M.J.; Buttner, M.J.; Chater, K.F.; Hopwood, D.A. (2000). Practical Streptomyces genetics. John Innes Foundation, Norwich, U.K.

22. Kozone, I.; Ueda, J.; Takagi, M.; Shin-ya, K. (2009). JBIR-52, a new antimycin-like compound, from Streptomyces sp. ML55. J. Antibiot. 62, 593-595.

23. Krasil'nikov, N. A. 1958 Soil Micro-organisms and Higher Plants. Moscow: Academy of Sciences of the USSR. PST Cat. No. 206.

24. Kumar, V.; Bharti, A.; Gusain, O.P.; Bisht, G.S. (2010). An improved method for isolation of genomic DNA from filamentous actinomycetes. J. Sci. Engg. Tech. Mgt. 2, 10-13.

25. Locci, R. (1989). Streptomycetes and related genera In: Williams, S.T., Sharpe, M.E., Holt, J.G. (eds). Bergey's Manual of Systematic Bacteriology. Williams, Williams company Baltimore, p.2451-2506.

26. Lu, C.G.; Lui, W.C.; Qui, J.Y.; Wang, H.W.; Liu, T.; Liu, D.W. (2008). Identification of an antifungal metabolites produced by a potential biocontrol actinomyces strain AO1. Braz. J. Microbiol. 39, 701-707.

27. Mba, C.C. (1996). Rock phosphate solubilizing Streptosporangium isolates from casts of tropical earthworm. Resource, conservation and recycling. 17, 211-217.

28. Misato, T.K.; Yamaguchi, I. (1977). Use of antibiotics in agriculture. Adv. Appl. Microbiol. 21, 53-88.

29. Mitra, A.; Santra, S.C.; Mukherjee, J. (2008). Distribution of actinomycetes, their antagonistic behaviour and the physico chemical characteristics of the world's largest tidal mangrove forest. Appl. Microbiol. Biotechnol. 80, 685-695.

30. Neu H.C. (1992). The crisis in antibiotics resistance. Science 257, $1064-$ 1073.

31. Ningthoujam, D.S.; Sanasam, S.; Nimaichand, S. (2009). Screening of 
Actinomycete Isolates from Niche Habitats in Manipur for Antibiotic Activity. Am. J. Biochem. Biotech. 5, 221-225.

32. Nonomura, H.; Ohara, Y. (1969). Distribution of actinomycetes in soil. VI. A culture method effective for both preferential isolation and enumeration of Microbispora and Streptosporangium strains in soil (Part 1). J. Ferment. Technol. 47, 463-469.

33. Parthasarathi, K.; Ranganathan, L .S; Anandia, V.; Josef, Z. (2007). Diversity of microflora in the gut and casts of tropical composting earthworms reared on different substrates. J. Environ. Biol. 28, 87-97

34. Shadomy, S. (1987). Preclinical evaluation of antifungal agents. In: Fromtling, R.A. (ed). Recent trends in the discovery, development and evaluation of antifungal agents. Prous Science, New Jersey, p.8-14.

35. Sharma, A.D.; Kainth, S.; Gill, P.K. (2005). Inulinase production using garlic (Allium sativum) powder as a potential substrate in Streptomyces sp. J. Food Eng. 77, 1-6.

36. Sharon, L.L.; Paul, F.H. (2001). Interaction of earthworm Diplocardia Mississippiensis (Megascolecidae) with microbial and nutrient dynamics in a subtropical spodosol. Soil Biol. Chem. 33, 1411-1417.

37. Shirling, E.B.; Gottlieb, D. (1966). Methods for characterization of Streptomyces species. Int. J. Syst. Bacteriol. 16, 313-340.

38. Sierra, G.A. (1957). A simple method for the detection of lypolytic activity of microorganisms and some observations on the influence of the contact between cells and fatty substracts. Anton. Lee. 28, 15-22.

39. Soares, A.C.F.; Sousa, C.D.S.; Garrido, M.D.S.; Perez1, J.O.; Almeida,
N.S.D. (2006). Soil streptomycetes with in vitro activity against the yam pathogens Curvularia eragrostides and Colletotrichum gloeosporioides. Braz. J. Microbiol. 37, 456-461.

40. Syers, J.K.; Springett, J.A. (2005). Earthworms and soil fertility. Plant soil. 76, 93-104.

41. Taber, W.A. (1960). Evidence for the existence of acid-sensitive actinomycetes in soil. Can. J. Microbiol. 6, 503.

42. Thumar, J.T.; Singh, S.P. (2007). Secretion of an alkaline protease from a salt- tolerant and alkaliphilic, Streptomyces clavuligerus strain MIT-1. Braz. J. Microbiol. 38, 766-772.

43. Vandamme, E.J. (1984). Antibiotic search and production: an overview. In: Vandamme, E.J. (ed). Biotechnology of industrial antibiotics. Dekker, New York, p. 3-31.

44. Wang, M.; Yang, X.H.; Wang, J.D.; Wang, X.J.; Chen, Z.J.; NXiang, W.S. (2009). New beta-class milbemycin compound from Streptomyces avermitilis NEAU1069: fermentation, isolation and structure elucidation. J. Antibiot. 62, 587-591.

45. Wu, X. C.; Chen, W. F.; Qian, C.D.; Li, O.; Li, P.; Wen, Y.P. (2007). Isolation and identification of newly isolated antagonistic Streptomyces sp. strain AP19-2 producing chromomycins. J. Microbiol. 45, 499-504.

46. Yuan, W.; Crawford, D.L. (1995). Characterization of Streptomyces lydicus WYEC 108 as a potential biocontrol agent against fungal root and seed rots. Appl. Environ. Microbiol. 61, 3119-3128. 